\title{
THE RELEVANCE OF REFORMED SCHOLASTICISM FOR CONTEMPORARY SYSTEMATIC THEOLOGY
}

\author{
DOLF TE VELDE*
}

Kampen Theological University

\begin{abstract}
This article examines how Reformed scholasticism can be relevant for systematic theology today. 'Reformed Scholasticism' denotes the academic practice in which the doctrines of the Reformation are expounded, explained, and defended. It is primarily a method and attitude in search of the truth, based on a careful reading of Scripture, drawing on patristic and medieval traditions, and interacting with philosophy and other academic disciplines. In addition to these methodological features, important contributions on various doctrinal topics can be discovered. The doctrine of God has a foundational role in the sense that God is the primary subject of the other topics (creation, salvation, etc.). Reformed scholastic theology not only examines God's inner essence, but also the concrete relation and operation of God toward his world. In a Trinitarian understanding of God's essence, a distinction is maintained between God's immanent relatedness as three divine Persons, and his outward relation to created reality. The doctrines of creation and providence gave occasion for Reformed scholastics to engage in debates with the emerging natural sciences, and also articulated important theological insights concerning the involvement of God in creaturely affairs. In Christology, the Reformed orthodox maintained the classic doctrine of the two natures of Jesus Christ, against Socinians and other opponents. These ontological statements are the necessary conditions for a proper understanding of the salvation by Christ. While the doctrinal positions of Reformed scholastic theology cannot be automatically transmitted to contemporary discussions, we can profit from this tradition on several levels of method and content.
\end{abstract}

KEY WORDS: Scholasticism, Holy Scripture, Trinity, Creation, Christology

\section{Introduction}

The past two or three decades witness a strong revival of interest in the theology of Protestant scholasticism (Trueman and Clark 1999/2007). In the United States, Richard A. Muller pioneered toward a groundbreaking reappreciation of Reformed scholastic theology on the basis of a comprehensive study of the sources (see especially Muller 2003a). At the same time, members of the theological department of Utrecht University, the Netherlands, developed their own tradition of research, directed by Antonie Vos and Willem J.

* DOLF TE VELDE (PhD 2010, Kampen Theological University) is associate professor of systematic theology at Kampen Theological University, the Netherlands, and associate professor of historical theology at the Evangelical Theology Faculty, Leuven, Belgium. Email: rttevelde@kampen.nl. 
van Asselt, and now hosted by the Institute for Post-Reformation Studies at the Evangelical Theology Faculty Leuven. It is no exaggeration to state that the field of Post-Reformation studies has been completely renewed.

In recent years, the fruits of the deepened historical understanding of the Reformed scholastic tradition are harvested in what becomes discernable as a 'theology of retrieval' or 'ressourcement'. While in Catholic theology this tendency dates back to the nouvelle théologie of Jean Daniélou, Henri de Lubac, and others (cf. Boersma 2009), a theology of retrieval made its entry in Protestantism only recently (Williams 1999; Webster 2007; Crisp 2010; Allen and Swain 2015). Characteristic of the retrieval movements is that they consider the conscious connection to the theological tradition of vital importance for the church today: the insights stored in the theological literature of past centuries have not been antiquated, but are still valuable as articulations of the Christian faith.

A second tendency in recent theology to which the study of Post-Reformation orthodoxy is connected is the emergence of 'analytic theology'. As Oliver D. Crisp describes, the development of analytic theology as a discernable approach to systematic theology represents a next phase in analytic philosophy of religion, which was in turn a specific application of analytic philosophy as such (Crisp 2011). Included in the 'rhetorical style' intended by analytic theologians are the 'intellectual virtues' of clarity, simplicity, and brevity, accompanied by logical rigor and conceptual analysis (Rea 2009: 3). In many respects, this recent movement resumes important insights, questions, distinctions, and arguments developed during the scholastic phases of theology in the Middle Ages and Early Modernity.

In what follows, I will give a brief introduction to the historical phenomena labeled as 'Reformed orthodoxy' or 'Reformed scholasticism'. I will indicate important aspects of the method and attitude of scholastic Reformed theology. The substantial contribution of insights from Reformed scholasticism on different fields of doctrine (doctrine of God, Trinity, creation and providence, Christology) will be discussed. The conclusion makes a statement on the continuing relevance of scholastic Reformed theology for today.

\section{Preliminary Definitions}

In this article, the term 'Reformed orthodoxy' and cognates will be used interchangeably with 'Reformed scholasticism'. 'Reformed scholasticism' refers to a form of theology that is historically situated in the period from ca. 1560 to 1750 , is embedded in the confessional and institutional identity of the emerging churches of the Reformed strand of Protestantism, is qualified by the application of a specific method deemed suitable for instruction, inquiry, and discussion on an academic level, and refers to a body of texts written in 
the distinct genres of 'question' and 'disputation'. Within the different ecclesial contexts, various types of scholastic theology were developed (cf. Trueman and Clark 1999/2007): Lutheran, Catholic (with as its foremost subtypes: Thomist, Scotist, and Jesuit forms of scholasticism), and Reformed.

'Scholasticism' is closely related to 'orthodoxy', that is, the stage of the Protestant churches (mainly Lutheran and Reformed) following the initial Reformation, in which their confessional identities were shaped and codified, and in which the Reformation turned from a protest movement into a set of well-established, separate ecclesiastical institutions (Muller 2003b: 33-36). Within the larger development of Orthodoxy, scholasticism is properly located in the context of the schools: it is theology as taught and developed in the classroom setting. The basic pattern of scholastic discourse is the question (quaestio): a clear presentation of the issue under discussion, followed by arguments pro and contra, and a solution by means of definitions and distinctions that respond to the initially stated positions (Muller 2003b: 27).

Since the first half of the 20th century, the emergence of scholastic theology in the churches of the Reformation was often characterized as a 'decline' from the genuine, evangelical insights of the Reformation (cf. Van Asselt and others 2011: 14-20). In fact, the notion of 'emergence' or 're-introduction' overlooks the fact that scholastic ways of doing theology have never been absent from the Reformational movements, both Lutheran and Reformed. From the start, Reformers with a more humanist outlook such as John Calvin were accompanied by theologians like Wolfgang Musculus, Peter Martyr Vermigli, Jerome Zanchi and others, who consciously operated in the scholastic traditions of biblical exegesis, doctrinal studies, and ethics (cf. Muller 2003a: $1: 52-67)$.

From the 1540s onwards, the deployment of scholastic approaches in Reformed theology was stimulated by three factors of practical necessity: confession, polemics, and education. Let me briefly explain each of these in turn. Next to the Augsburg Confession authored by Philip Melanchthon, several groups of churches in Switzerland, Germany, France, the Netherlands, and the British Isles formulated their own doctrinal standards. Though different in genre from the properly academic forms of scholastic discourse, these confessional documents that were mainly produced from the 1520 s to the $1570 \mathrm{~s}$ witness a comprehensive and systematic grasp of the main points of the Christian faith, which is expounded both positively and polemically.

The formation of confessional identities was accompanied by the need for a polemical defense of doctrine. During the sixteenth century, the Reformed theologians constantly felt obliged to explain and justify their positions over against the Catholic Church, and later on also in response to Lutheran theology, concerning issues such as Scripture versus tradition, justification and 
grace, the sacraments, Christology and predestination. All these fields of doctrinal debate required the abilities of logical reasoning, of conceptual analysis of the relevant parts of Scripture, as well as a profound knowledge of the patristic and medieval traditions to which most parties wished to appeal.

The third factor that was instrumental in the rapid rise of scholastic forms of Reformed theology is the training of new generations of ministers of the Word. Soon after the Reformation, it was felt that for the transmission of the Reformed faith a system of methodical instruction was needed. For this purpose, new institutions of higher education were founded all over Europe, starting with the Genevan Academy in 1559 and the almost simultaneous 'Calvinist' reconstruction of the University of Heidelberg during the years 1558-1561, and soon followed by the foundation of Leiden University in 1575 and similar academies in Herborn, Franeker, Steinfurt, Saumur, and other places. In fact, these schools provided the natural and proper context for scholastic theology of a Reformed signature.

In sum, the revival of scholastic ways of doing theology since the $1550 \mathrm{~s}$ was the natural and indispensable sequel to the formative decades of the Reformation since 1517. In order to survive, the newly discovered insights and approaches had to be expounded, transmitted, and defended in a sophisticated and well-structured manner.

\section{Method and Attitude}

As the above sketch makes clear, scholastic theology is in itself not identical with a particular set of doctrinal positions. Rather, it is an argumentative approach to the investigation, exposition, clarification, and defense of Christian doctrine. Already in this sense, understood as a method and an attitude, the scholastic Reformed theology of the orthodox era is helpful for present-day systematic theology in many respects:

First, engaging in Reformed orthodox theology is a means of staying connected to the Catholic tradition of Christianity. From the beginning of the Reformation movements in the 17th century, Protestants have attempted to maintain a vital connection to the broad Christian tradition stretching back to the early church. In this regard, the formation of a scholastic type of theology is a strong expression of the desire to stand in a universal and ecumenical community of faith and doctrine (cf. the essays collected in Van Asselt and Dekker 2001).

Compared to medieval culture, the early modern period shows the emergence of a stronger sense of individuality. Still, the development of Reformed scholastic theology was not the effort of a few individuals. It was a multi-centered enterprise of academic institutions in which scholars co-operated for the sake of creating a common, supra-personal understanding of the Christian doctrines. Just as in medieval scholasticism, the Protestant scholastics of 
the early modern era worked in the sphere of a 'unified science' (Vos 2001): a common level of understanding in terms of concepts, argumentative strategies, and presuppositions, which enabled the exchange of ideas beyond the boundaries of confession, profession, and nationality.

The Catholic or ecumenical dimension of the scholastic way of doing theology safeguards against personal individualism, and also against ecclesial or confessional narrow-mindedness. To be sure, theologians of the Orthodox era would normally hold consciously to the confessional boundaries that were established between Protestants and Catholics, and also between Lutherans, Calvinists, Anabaptists, and others. At the same time, however, precisely because scholastic theologians on different sides of the confessional borders did care about the truth claims implied in their doctrinal positions, they insisted on the need of debate with opponents from other churches and traditions in which we can often discern a genuine exchange of arguments on the common basis of Scripture and tradition.

Second, a further point of continuing relevance of Reformed scholasticism lies in its appeal to Scripture as the foundational source and norm of doctrine. In popular understanding, the Reformation of the 16th century is seen as a radical break with the preceding theology of the Middle Ages, generatingin close company with the humanist movement toward the sources (ad fontes)-an entirely new understanding of the message of the Bible. Indeed, the different strands of the Reformation departed from an interpretation of Catholic doctrine in which the written or unwritten tradition of the church was placed on a par with Scripture as authoritative norms of faith and life. A a representative exposition of the Reformed doctrine of Scripture, in critical engagement with Roman Catholic theology can be found in the Synopsis purioris theologiae of 1625 (Te Velde and others 2014: 48-149).

The emphasis on the sola Scriptura principle issuing from the Reformation, however, obfuscates the underlying continuities (Muller 2003a, vol. 2 passim). It fails to do justice to the permanent practice of reading the Scriptures-devotionally and professionally—which forms the natural embedding of theology throughout the Middle Ages. Much of the concepts, distinctions, and arguments deployed by scholastic thinkers were occasioned by the need to clarify questions arising from biblical texts and other authorities. The development of early Reformed scholastic theology manifests a similar grounding in the authority and exposition of Scripture. During the first and second generations of Reformers, we can detect a two-way relationship between Scripture and doctrine. First, detailed exegesis examines individual texts and derives more general doctrinal points from them; this is the original genesis and meaning of loci communes ('common places') as evidenced in many sixteenth century biblical commentaries by, e.g., Bucer, Vermigli, Zanchi. Second, the loci communes thus found are further investigated in their conceptual 
meaning, implications, and relations, a procedure in which the biblical evidence recurs in a different form (the legitimacy of this second procedure was advocated by, for example, Ursinus and Zanchi). Given this state of affairs, Richard Muller has argued that what may appear to be uncritical 'proof texting' in dogmatic handbooks or disputations does in fact reflect a tradition of careful exegetical analysis (Muller 2003a: 2:113).

Third, theology in the era of Reformed orthodoxy did consciously occupy its place in the universities and other academic institutions of Early Modernity. In fact, the theological faculties often were among the first and foremost departments of the young universities. Theology in the Reformed orthodox era understood itself as part of the academic culture of the time, and thus was involved in the common quest for truth.

Principally, Reformed theology endorsed the view that all truth is in the final analysis one (on this principle as advocated by Bartholomaeus Keckermann, see Muller 2003b: 122-136). For that reason, it could not evade the responsibility of demonstrating and clarifying the doctrinal contents in an argumentative way. The strong incentive to make the contents of faith understandable in relation to other domains of knowledge produced a form of theology that can still be useful to the field of apologetics, both to clarify the implications of the Christian faith and to refute objections which are often based on misunderstandings or on problematic logical premises. It is important to note that the Reformed scholastic insistence on the principal harmony of faith and reason differs from the early Socinian claim (which was later commonly held by other rationalists) that the truths of faith may be 'above reason' (supra rationem), but are never 'against reason' (contra rationem). While the Socinians gave in fact the primacy to human reason as an independent judge of truth, and rejected classic doctrines such as Trinity and Christology on rational grounds, the Reformed scholastics took the revealed truths of faith as their starting point, and on this basis attempted to demonstrate the rational intelligibility and consistency of these articles (Te Velde 2013: 100-106).

The interaction between theology and the other disciplines was multi-faceted. The relation to philosophy, in particular, has received much attention in recent historiography. The popular impression that Reformed theologians defended a backward approach, clinging to an antiquated Aristotelian philosophy while the tides were turning to the new philosophies of the Enlightenment, deserves some refinement and correction. During the 15th and 16th centuries, many discoveries were made into the original writings of Aristotle, and new versions of 'Aristotelian' philosophy were devised by-among others-Philip Melanchthon, Francesco Suarez, Clemens Timpler, and Johann Heinrich Alsted. These early modern systems of philosophy-drawing on 
medieval models-were intentionally developed in accordance with the central tenets of the Christian faith (cf. Frank and Selderhuis 2012). When the famous debates between philosophers such as René Descartes and Baruch Spinoza and Reformed theologians started in the middle of the 17th century, considerable theological interests were at stake. Judged by the standards of that time, the new philosophical ideas promoted by Descartes and others were far from rationally self-evident; they could be countered by arguments that even in retrospect laid bare serious weaknesses and antinomies of the nouvelle philosophie (Verbeek 1992; Goudriaan 1999).

\section{Doctrinal Substance}

In addition to the general relevance of Reformed orthodox theology in terms of method and attitude, it is also profitable to be acquainted with this tradition of theology because of the insights developed in several areas of doctrine. Within the limits of this article, we will survey four fields of doctrine: the doctrine of God, of the Trinity, of creation and providence, and Christologyleaving unmentioned the many other valuable insights which might be found in some many other loci.

The Doctrine of God

This part of doctrine is particularly well researched in recent Post-Reformation studies (Muller 2003a, vol. 3; Beck 2007; Te Velde 2013, part I; Rehnman 2013). Because of its foundational status, the concepts and arguments developed in the doctrine of God have a regulative function for the other loci. Although Reformed theology does not follow a fixated order of doctrines, there is a fairly common practice to start with Scripture as the 'cognitive foundation' and the doctrines of God and Trinity as the 'primary subject' of theology. Most authors then continue with a roughly historical sequence of creation-sin-Christology—salvation-Church and sacramentscivil life-eschatology. In relation to these topics, theology proper has a foundational function in a number of respects:

First, the doctrine of the divine names provides the starting point and serves as an elementary theory of the knowability of God. It is stated that we can know God only because God reveals his own name(s) in Scripture. The biblical names of God are interpreted as signifying either God's essence or God's properties. Among the biblical foundations, the revelation to Moses of the divine name YHWH (Exodus 3 and 6), and the divine self-portrait in Exodus 34, stand out as sources of revealed insight in God's being. The Reformed orthodox theory of 'knowing God' consists of two complementary insights. On the one hand, it points to the inadequacy of our knowledge of God due to our limited capacity of understanding. The difference between Creator and creature, strongly increased by human sinfulness, makes it impossible 
for us to have full and adequate knowledge of God. On the other hand, the Reformed orthodox reject religious agnosticism and advocate the possibility of a positive knowledge of God on the basis of gracious, supernatural revelation. The combination of these two insights results in a nuanced positionechoing medieval scholastic discussions and distinctions-in the question how creaturely concepts can be predicated of God: the road taken in predicating terms of God is neither equivocal nor univocal, but analogous. There is both a decisive difference and a certain similarity in the application of terms to God and creatures (cf. Te Velde 2013: 114-124, 246-247).

Secondly, the Reformed orthodox reflect on the existence and essence of God. In general, they hold the existence of God to be self-evident. In the context of the sixteenth and seventeenth centuries, theoretical atheism as the deliberate denial of (the possibility of) God's existence was not a live option. The proofs for the existence of God mostly presented by the Reformed orthodox are taken from causality, order, and universal consent. In combination with the causal argument, medieval argumentations in more ontological and modal terms (Anselm, Duns Scotus) are reiterated as well. The Reformed orthodox discussion of God's existence shows that they had to face new philosophical and cultural movements (Socinianism, Cartesianism, Spinoza, Hobbes) that openly or implicitly undermined the former universal consent of the people (consensus gentium) on this point (Goudriaan 1999: passim; Te Velde 2013: 124-127; Muller 2003a: 3:170-195). In that connection, it should be welcomed that in our time where the denial of God's existence has become en vogue, the tradition of natural theology and of theistic proofs is continued, mainly by analytic philosophers and theologians. Rather than providing straightforward 'evidence' for the existence of God, these arguments may help us articulate some of the rational implications for our worldview of either the acceptance or the denial of God.

In discussing the essence of God, the Reformed orthodox maintain the importance of the term 'essence' or 'nature', although they acknowledge that no complete definition of God's essence can be given. Part of the urgency for Reformed orthodoxy to maintain the 'essence' language is the confrontation with the Socinians, who effectively dissolved the divine essence into its separate operations and effects (cf. Te Velde 2012). The descriptions of God's essence given by Reformed orthodox authors mostly include a Trinitarian formula, and the enumeration of basic attributes such as uniqueness, spirituality, simplicity, eternity, wisdom, goodness, and power.

Third, the doctrine of the divine attributes elaborates the statements on God's essence. It is made clear that no real distinction can be made between God's essence and his attributes. This denial of real differences-as a difference between two separate 'things' - within God's essence does not prevent 
Reformed orthodoxy from discussing God's attributes in mostly two (sometimes three or four) groups (Muller 2003a: 3:195-226; Te Velde 2013: 129138).

The first sort of attributes (incommunicable) circumscribes the essence of God as different from created reality. God is free from the compositions that characterize creatures; God is not dependent on anything outside Godself; God is without limits and thus free from temporal and spatial boundaries; God is not subject to changes; God is, in one word, perfect. Although the formal outlook of this part of the doctrine of God is negative (the negations of created properties dominate), it results in a highly positive concept of God as a Being that is superior to all classifications and limitations we can think of. In discussing these attributes we see the Reformed orthodox struggle with concepts such as causality, essence and existence, incomprehensibility, space and time, resulting in the insight that the standard Aristotelian categories of thought fail to apply in relation to God.

The second group of attributes (communicable) consists of divine properties that in some degree resemble qualities in creatures. Because of the unity of God's essence, the attributes of the second group are qualified by the preceding properties, especially simplicity, aseity, and immutability. An important function of this second group is to express the way in which God relates to the world outside Godself. Often, the initial attribute of this group is the life of God, the analysis of which provides the subsequent trichotomy in knowledge, will, and power. The prominent inclusion of God's life among the attributes of the second group contradicts the suggestion that the scholastic concept of God is static and lifeless.

The analysis of God's life into the three 'faculties' of knowledge, will, and power, follows a long tradition of theology that applies the Aristotelian division of the human (psychological) faculties to God. Basic to this theory is the elementary insight that God knows, wills, and can do things. These concrete acts presuppose a threefold capacity which God always has at his disposal. Each of these has some attributes added to it; especially the 'affects' or 'virtues' adjacent to God's will receive considerable attention. The extensive discussion of these affects shows at once the strong motive to incorporate into the doctrine of God all elements of the biblical testimony concerning God, and the soteriological motive to describe the attributes of God that directly affect humanity in the course of salvation (justice, grace, mercy).

The abiding importance of the Reformed scholastic account of the doctrine of God can be indicated in the following points:

1. While clearly based on the concrete self-revelation of God in Scripture, it takes up the challenge of thinking through the implications of the biblical statements in terms of ontological concepts and their logical 
relations, both internally-analyzing and relating the notions connected to the nature or essence of God-and externally-in view of God's operations toward the created world. In doing so, Reformed orthodox theology accounts for the coherence and intelligibility of the Christian speech about God.

2. The Reformed scholastic positions on the possibility of providing arguments for God's existence present a warning against an overly optimistic valuation of the human mind's capacity for grasping the truth of God. At the same time, since in our times the need of an apologetic explanation of the Christian belief is urgently felt, the arguments for the existence of God as developed in Reformed orthodox theology can be revitalized. For our atheistic or agnostic contemporaries, it does make sense to be confronted with the consequences of the denial of God for our understanding of ourselves and the world.

3. A specific field of apologetics lies in the conversation with other religions. While the interreligious dialogue has many epistemological, spiritual, and doctrinal aspects, the question 'Who is the God who is worshipped in this particular religion?' deserves a central place. The elaborate doctrine of divine attributes provides a set of properties by which the deities of other religions can be examined and compared to the God of the Bible. On a closer look, the classic Reformed doctrine of God does not endorse a general, religiously neutral concept of 'God', but reflects the character of the Triune God as revealed in the history of Israel and, ultimately, in the incarnation of the Son of God. We can also spell out the spiritual and practical implications of differences in the basic conceptions of deity in relation to, for example, prayer and ethical conduct.

4. As the above sketch has made clear, it is not true that the Reformed scholastic doctrine of God yields a static, abstract picture of an 'unmoved Mover'. Large portions of theological discussion are devoted exactly to the active relation of God to his world. At the same time, Reformed orthodoxy maintains that God's external operations are rooted in and governed by his own inner being. In this connection, the incommunicable attributes of God function as the ontological prerequisites of the concrete historical and relational dealings of God with his creatures.

\section{The Doctrine of the Trinity}

Karl Barth powerfully insisted on the doctrine of the Trinity as the basis and presupposition of all Christian doctrine (Barth 1932). Following his lead, and encouraged by Karl Rahner, John Zizioulas, and others, many recent theologians have criticized earlier theology for a lack of Trinitarian awareness. This 
failure affects both the sources from which concepts and ideas concerning God are taken (philosophy vs. Scripture) and the character of the Godhead itself: without the crucial notions of Trinity, God is a static, abstract and impersonal entity that can hardly be conceived as our loving Father and our gracious Savior.

Is this a fair judgment? In the first place, when taking the whole of Reformed orthodox theology into consideration, it is obvious that these theologians subscribed to the doctrine of the Trinity as strongly as any recent defendant. The Reformed scholastics fully incorporated the classic dogma of the Trinity into their confessions and theology. Moreover, the Reformed orthodox actually had to face severe attacks on the doctrine of the Trinity in the sixteenth and seventeenth centuries. In response to Unitarian freethinkers such as Servetus, Biandrata, Stancaro and others, outstanding theologians like Calvin himself (Baars 2004), Peter Martyr Vermigli, and Girolamo Zanchi wrote extensive treatises in order to explain and defend the doctrine of God as one essence in three Persons. Keeping to the Trinitarian Creed was not only a matter of tradition: they saw this confession as vital for the Christian faith as such.

Secondly, in many places of their expositions of the doctrine of God, the Reformed orthodox do make the connection with the doctrine of the Trinity. The Reformed orthodox are very cautious in providing a definition or description of the divine essence. These descriptions often are stated in terms of 'a most simple, infinite Spirit', which indeed sounds fairly abstract. Immediately connected to such terms, however, we frequently find explanations in terms of 'Father, Son, and Holy Spirit' or 'the God of Israel' (cf. the material covered by Muller 2003a: 3:227-233). This indicates that even where the Reformed scholastics employed abstract terms to describe God, they kept the concrete Trinitarian existence of God in mind. Moreover, in discussing the divine attributes, they often explicitly related these to the doctrine of the Trinity, for example when it comes to God's simplicity, independence, and perfection.

Third, we should understand that Reformed theology from the sixteenth century onward opted for the locus method: the doctrinal topics are discussed in separate chapters that are loosely connected in a certain systematic order. The division and sequence of those chapters does not necessarily determine the substance of doctrine. Each locus, though connected with the others, has its own scriptural, traditional and conceptual material. With respect to the doctrines of God and of Trinity, it is clear that they belong together in examining the essence of God. At the same time, both have their specific focus and complex of problems (Muller 2003a: 3:156-159; Beck 2007: 227-232). 
Recent Protestant theology shows a wide consensus on the necessity of connecting the doctrine of God to the doctrine of the Trinity. Reformed theology does not need to refrain from this consensus, as far as the personal identity of God is emphasized by reference to the doctrine of the Trinity. The 'Trinitarian renaissance' of the past three or four decades has in particular promoted various versions of social Trinitarianism (for a recent survey, see McCall 2010). Typical of the social or relational understanding of the Trinity is that not only the distinct Persons with their mutual relations receive extra attention, but that also the relational character of the Trinity is extended to us, who are as humans invited to participate in God's Triune community.

In this connection, the Reformed orthodox accounts of the Trinitarian dogma give reason for some qualifications. It is noteworthy that the great proponent of a Trinitarian theology, Karl Barth, maintained-in line with classic theology-in his doctrine of the Trinity a firm distinction between God's own triune life as Father, Son, and Spirit-labeled by Barth as God's 'primary objectivity' - and his revealing himself in God's external gracious relations and actions-God's 'secondary objectivity' (Barth 1940: 15-24; for a more detailed analysis, see Te Velde 2013: 423-446). Starting from this basic conviction, Barth indeed contends that God's internal communicative and relational character is the root and prototype of God's communication and relatedness towards his creatures. But acknowledging the structural difference between primary and secondary objectivity or relatedness implies that the latter is not an immediate, necessary, and ontological continuation of the former. God's gracious relationship with us rests on God's will, and thus is not constitutive for God's being, although it is firmly rooted in God's essence and genuinely expresses the essential goodness of God (for a survey of the recent debates in the reception of Barth, see Dempsey 2011).

For systematic theologians, it is appealing to construe coherent, symmetrical and parallel sets of ideas. Thus, one might be induced to treat the doctrine of the Trinity as a structural principle (Rahmentheorie) that can be made functional in other parts of doctrine (cf. Metzger 2005). I would, however, be cautious in doing so. The doctrine of the Trinity is the church's answer to the specific question of how Jesus Christ and the Holy Spirit relate to the God of Israel. For that reason, a certain reserve is in place when the doctrine of the Trinity is treated as the solution to the problem of unity and differentiation, or singularity and plurality, in general.

In a more limited sense, insights gathered from the doctrine of the Trinity can modify or color the exposition of God's essence and attributes. It does make sense, for example, to start the exposition of God's knowledge and wisdom with the fact that the Son of God is God's wisdom in person; although it is not easy to point out the full implications of this equation. The confession of God as triune prohibits the interpretation of God's immutability as static 
and monolithic unity. The account of divine omnipotence, as a final example, should do justice to God's care for his creation, the suffering of Christ as the way in which God overcomes evil, and the soft irresistibility of the Spirit.

\section{Greation and Providence}

The doctrine of creation has been one of the central tenets of the Christian faith throughout the centuries. Of course, we cannot expect direct contributions from the Reformed scholastic doctrine of creation to the present-day debates concerning the origins of the universe and of the human species (as one among others). The momentous increase in scientific knowledge and the consequent changes in worldview and orientation make it impossible to endorse exactly the same positions as were defended in Reformed theology in the 16 th to 18 th centuries.

On several other levels, however, the Reformed orthodox account of creation and providence contains important notions that can be fruitfully employed in a 21 st century theology of creation. To begin with, the identification of the world we live in as God's creation amounts to a principal de-sacralization of the world. The world itself is not divine or sacrosanct. The world as it exists is not eternal, nor necessary, nor unchangeable. By acknowledging the contingent and non-divine status of the created world, Christian theology in general and Reformed theology in particular stands open for free scientific research of reality in all its aspects. Early Reformed theologians such as Lambert Daneau, Girolamo Zanchi, and others incorporated extensive expositions of all God's works in the six-day creation of the world in their theological systems.

An intriguing aspect of how Reformed orthodoxy developed its theology of creation surfaces in its initial resistance to the 'Copernican revolution' in astronomy. Gisbertus Voetius, for one, continued to defend the rotation of the sun around the earth on the basis of an assumed Physica Mosaica, while apparently neglecting the empirical data that became gradually available for the contrary position. In defense of Voetius, we can reckon with the fact that the shift toward a heliocentric model went along with more far-reaching revisions of physics in the Cartesian movement. As Andreas Beck has argued, the new cosmology was often presented together with a denial of the 'substantial forms' that were fundamental to Aristotelian (meta)physics. In the eyes of Voetius and others, this package deal had disastrous theological and philosophical consequences. While Voetius had good reasons-within the academic discourse of that time-to defend a geocentric worldview, other Calvinists made the Copernican turn sooner or later with equally good—or, in hindsight, better-reasons. The fundamental issue here is not the doctrine of creation proper, but rather the hermeneutical question of how to handle the 
tension between the apparent teaching of Scripture and the increasing evidence from the natural sciences (Beck 2007: 65-68, 86-90; Vermij 2002).

Even in a context where the affirmation of creation as a divine work performed within six days a few thousands of years ago is no longer plausible, Reformed orthodox theology contributes some substantial theological insights that deserve consideration. The first regards the beginning of the world. Even if the beginning of the world cannot be determined chronologically, it remains a fundamental question whether or not the world has-absolutely speaking - a beginning. Reformed scholastic theology commonly held to the view of Augustine, 'that God founded this world within time, $\mathrm{He}$ did so freely, too, and according to the good pleasure of his own will (...) [the world] which He could have created earlier or later in time ...' (Te Velde and others 2014: 254-255). My suggestion is that even though nowadays cosmology and astronomy count with a scale of billions, not thousands of years, there are still theological (next to scientific!) reasons to insist on a temporal beginning of the world. In any case, from the almost unimaginable age of the earth according to standard chronology it does not follow that the universe is in fact without a beginning, or, theologically speaking, eternal.

Connected to the statement that the world has a temporal beginning is the Reformed scholastics' insistence on the ontological distinction between God and the created world. God exists in his own necessary way, independent from the world, eternally perfect in his own Triune life. The world, in turn, exists in a contingent way, dependent on the will of God for both its coming into existence and its continuing to exist, imperfect and finite in spite of its extension. This specific relation between God and the created world does not only account for the contingency and freedom that is essential for our creaturely existence; it also means that our lives and everything else in the universe have a goal and destination that is determined by God. The fact that God has willed us in the way we are (apart from sin), gives us a sense of purpose and of value, which the explanation of life in terms of impersonal, naturalistic evolution cannot provide.

In scholastic Reformed theology, the doctrine of creation has a direct sequel in the doctrine of providence. As Andreas Rivetus puts it in the Leiden Synopsis purioris theologiae, it is not true that when God 'had accomplished and finished everything completely, He put away from himself every care for it' (Te Velde and others 2014: 261). In the notion of providence, the very existence of God as a personal agent is at stake: 'since God is the cause of everything, and since every agent acts for the sake of a goal, it follows thereupon that God, who cannot be God and lack wisdom, ordains everything towards its own goal' (Te Velde and others 2014: 265). 
With the rise of the natural sciences, the concept of causality received a strongly immanent and determinist twist. According to the Reformed orthodox account of providence (as well as its Lutheran and Catholic counterparts), the chains of natural causes which operate according to natural laws do not exist independently: they are constituted and sustained by God's primary causality. This means that God's involvement as the Creator of the world need not be explained away when humans gain more knowledge of how the natural processes operate: on his own level of causality, God is the origin and warrant of all that happens, be it performed by natural or by free (personal) causes.

In relation to free or personal causes, the providence of God takes a particular character. At face value, the determination and governance by God as the primary cause seems to rule out genuine freedom on the secondary level of human causality. The Reformed scholastics, however, developed a strong but nuanced view of God's involvement in human actions. Far from destroying the freedom of the human will, the providential will of God is in fact the source from which our will derives its freedom. Because God's creative will is most free, the created world produced by this will displays structural freedom. Humans and their free acts of will are included in God's decree of God's governance exactly in their nature and mode of being free and contingent (Van Asselt, Bac, Te Velde 2010).

The critical test of the concept of providence comes in relation to evil. As such, the conceptual clarification aimed at by scholastic Reformed authors does not provide spiritual comfort in the face of evil. What it can provide, however, is a solution of rational problems elicited by the experience of evil, problems that affect the understanding of the relation between God and the person afflicted by evil (arguments taken from Disputation 11-On the Providence of God, in Te Velde and others 2014: 260-283). A couple of insights can be mentioned here.

First, the Reformed orthodox position should be distinguished from the later, Leibnizian notion of the 'best of all worlds'. There is no necessary connection between God's own essential goodness and one prescribed course of good events. Since the world exists not by God's nature, but by his will, there is a fundamental freedom of choice for God which of several 'goods' He is willing to actualize.

Second, it is not up to us humans to determine what is good in an absolute and comprehensive sense. The Reformed scholastics state that God, by his providence, establishes a teleological order of means towards an end. This does not imply, however, that we can understand the good purposes devised by God, nor should we assume that there is a direct and uncomplicated relation between particular events and the ultimate good. 
A third element of the Reformed orthodox account of evil in view of God's providence is to make a distinction between different ontological aspects of an evil act. Viewed apart from its moral quality, an evil act as such has the status of an entity (or event) that exists in reality, and can as such be willed by God. Insofar as these same actions, however, are morally defective, they cannot be attributed to any act of God but merely to the human agent.

The fourth and perhaps most important notion dealing with the relation of providence to evil is the concept of 'permission' (permissio). By incorporating the notion of permission, Reformed scholastics tacitly correct John Calvin's rejection of divine permission. Distinct from the effective will by which God wills all good things in a direct and active way, his permissive will indicates an indirect, second-order act of God towards evils things. To be sure, 'permission' is not the absence of willing; it should not be understood as a merely passive 'let it go' toward evil. At the same time, God wills, in his permission, evil only in an indirect way. By stating that God wills the occurrence-or, to put it more restrictively-the non-prevention of evil which $\mathrm{He}$ does not approve of, Reformed scholastic theologians propose to see the evil deeds of humans and their consequences as included in the domain of God's providential governance, and therefore as not falling outside God's control, while at the same time maintaining the moral perfection of God on the one hand and the moral accountability of created evildoers on the other hand.

\section{Christology}

In Christology, as in many other areas of Christian doctrine, the paradigms of thought have changed drastically during the last two centuries. While the Calvinist and Lutheran reformers of the $16^{\text {th }}$ century, followed by their scholastic successors, continued to affirm the statements of Chalcedonian orthodoxy against the Socinians and other early rationalists, the rise of historicalcritical scholarship in biblical studies has had enormous consequences for the systematic understanding of Jesus Christ and his work (McGrath 2005).

Initially, the application of source criticism to the four Gospels created a distance between what was constructed as the authentic self-understanding of the 'historical Jesus' and the theological affirmations developed by the first generations of his followers. On a more philosophical level, the doctrine of the unity of the divine and human natures in Christ seemed no longer intelligible or plausible, because it seemed to combine contradictory properties in one person, and because the whole way of thinking in terms of essence, natures, and properties has become obsolete. Along with the denial of the traditional Logos Christology came several proposals to understand the relation between Jesus and God in new ways, with Jesus being seen either as the ultimate moral example of love and obedience toward God, or as the unique messenger of God's revelation, or as the 'Son of man' who was 'adopted' as 
Son of God through the special indwelling of the Holy Spirit, or in yet another way.

In this climate of modern theology, the traditional interpretation of Christology along Chalcedonian lines needs some extra explanation. Fortunately, Reformed scholastic treatments of this doctrine contain helpful insights which can enrich systematic-theological discussion today. First, the modern tendency to replace concepts of substance, nature, and properties by more existentialist, functional, and relational categories, should not be taken for granted. With some effort, the classic categories as employed in the Christological doctrine of the church can still be made understandable for contemporary audience. More importantly, the Chalcedonian insistence on Christ being 'truly God and truly man' (vere Deus-vere homo) requires some sort of articulation in terms of nature(s) and person. When Christ claims that 'I and the Father are one' (John 10:30), this should not be understood as merely a unity of will or power, but it has the underlying implication of a unity of essence or identity.

Second, the Reformed scholastics did not interpret the unity of God and man in Christ as a purely abstract, ontological principle. The concrete, historical event of the incarnation was viewed as constitutive: it is through the assumptio carnis that the Son of God became man. The contingent and redemption-historical character of the incarnation prevented the Reformed orthodox (at least most of them!) from speculating about the necessity of the incarnation apart from the occurrence of sin. Along the same lines, the specific character and purpose of the unity of God and man in Christ should be maintained today against theologies that turn incarnation into a universal principle of unification between God and humanity, or that advocate a neognostic idea of a 'Christ-spirit' that secretly dwells within every human being.

Third, the statements about the Person of Christ are inextricably linked up with the soteriological work of Christ as the Mediator of God and humankind. Not only is the incarnation of the Son of God motivated by the salvation of lost sinners, also the performance of this work of salvation and requires the specific constitution of his Person as God-and-man. As was already pointed out by Athanasius in the Arian controversy, if it is not truly God who came in Christ, the world is not truly redeemed from sin and death. The other way around, Gregory of Nazianzus (Letter to Cledonius, PG 37, 181) argued that 'that which was not assumed, is not healed' (quod non assumptum, non sanatum). In early medieval scholastic thought, these two lines were further elaborated by Anselm of Canterbury in his Cur Deus homo. The Reformed scholastics in turn-following the Heidelberg Catechism—stand firmly in this line of connecting Christology and soteriology. 


\section{Conclusions}

Reformed orthodox theology flourished in the era between 1560 and 1750 . In many respects, the cultural, ecclesiastical, and intellectual contexts of Western theology have changed drastically since those days. Still, it is worthwhile to study the writings of scholastic Reformed theologians, to explore their concepts and arguments, and to bring their insights into fruitful conversation with present-day discussions in systematic theology.

Recent tendencies such as retrieval theology and analytic theology show that the approaches and techniques developed in the scholastic phase of Reformed theology are not outdated, but continue to be relevant. This is not to say that form and content of Reformed theology from the 16th and 17th centuries can be transmitted to our time on a one-by-one basis. What we can learn from scholastic Reformed theology is an open-minded, Scripture-oriented, and intellectually rigorous attitude, together with a set of substantial convictions that can still be held today as promising articulations of the Christian faith in a post-Christian, multi-religious world.

\section{Bibliography}

Allen M, Swain SR (2015) Reformed Catholicity. The Promise of Retrieval for Theology and Biblical Interpretation. Grand Rapids, MI: Baker Academic.

Baars A (2004) Om Gods verhevenheid en Zijn nabijheid. De Drie-eenheid bij Calvijn. Kampen: Kok.

Barth K (1932) Kirchliche Dogmatik I/1: Die Lehre vom Wort Gottes. Munich: Chr. Kaiser.

Barth K (1940) Kirchliche Dogmatik II/1: Die Lehre von Gott. Zollikon: Verlag der Evangelischen Buchhandlung.

Beck AJ (2007) Gisbertus Voetius (1589-1676). Sein Theologieverständnis und seine Gotteslehre. Göttingen: Vandenhoeck \& Ruprecht.

Boersma H (2009) Nouvelle Théologie and Sacramental Ontology. A Return to Mystery. Oxford: Oxford University Press.

Crisp OD (2010) Retrieving Doctrine. Explorations in Reformed Theology. Milton Keynes: Paternoster.

Crisp OD (2011) Analytic Theology. Expository Times 122(10): 469-477.

Dempsey MT, ed (2011) Trinity and Election in Contemporary Theology. Grand Rapids, MI: Eerdmans.

Frank G, Selderhuis HJ, eds (2012) Philosophie der Reformierten. Stuttgart-Bad Cannstatt: Frommann-Holzboog.

Goudriaan A (1999) Philosophische Gotteserkenntnis bei Suarez und Descartes im Zusammenhang mit der niederländischen reformierten Theologie und Philosophie des 17. Jahrhunderts. PhD thesis, Rijksuniversiteit Leiden. 
McCall TH (2010) Which Trinity? Whose Monotheism? Philosophical and Systematic Theologians on the Metaphysics of Trinitarian Theology. Grand Rapids, MI: Eerdmans.

McGrath AE (2005) The Making of Modern German Christology 1750-1990, second edition. Eugene, OR: Wipf and Stock.

Muller RA (2003a) Post-Reformation Reformed Dogmatics. The Rise and Development of Reformed Orthodoxy, ca. 1520 to ca. 1725, 4 volumes, Grand Rapids, MI: Baker Academic.

Muller RA (2003b) After Calvin. Studies in the Development of a Theological Tradition. New York, NY: Oxford University Press.

Rea MC (2009) Introduction. In Crisp OD and Rea MC (eds) Analytic Theology. New Essays in the Philosophy of Religion. Oxford: Oxford University Press, pp. 1-30.

Rehnman S (2013) The Doctrine of God in Reformed Orthodoxy. In Selderhuis HJ (ed) A Companion to Reformed Orthodoxy, pp. 353-401.

Selderhuis HJ, ed (2013) A Companion to Reformed Orthodoxy. Leiden: Brill.

Te Velde D (2013) The Doctrine of God in Reformed Orthodoxy, Karl Barth, and the Utrecht School. A Study in Method and Content. Leiden: Brill.

Te Velde D and others, eds (2014) Synopsis purioris theologiae / Synopsis of a Purer Theology, volume 1. Leiden: Brill.

Trueman CR and Clark RS, eds (1999) Protestant Scholasticism. Essays in Reassessment. Carlisle: Paternoster; reprinted as Trueman CR and Clark RS, eds (2007) Protestant Scholasticism. Essays in Reassessment. Eugene, OR: Wipf and Stock.

Van Asselt WJ and others (2011) Introduction to Reformed Scholasticism. Grand Rapids, MI: Reformed Heritage Books.

Van Asselt WJ, Bac JM, and te Velde DT, eds (2010) Reformed Thought on Freedom: The Concept of Free Choice in the History of Early-Modern Reformed Theology. Grand Rapids, MI: Baker Academic.

Van Asselt WJ and Dekker E, eds (2001) Reformation and Scholasticism. An Ecumenical Enterprise. Grand Rapids, MI: Baker Academic.

Verbeek T (1992) Descartes and the Dutch. Early Reactions to Cartesian Philosophy 1637-1650. Carbondale, IL: Southern Illinois University Press.

Vermij R (2002) The Calvinist Copernicans. The Reception of the New Astronomy in the Dutch Republic, 1575-1750. Amsterdam: Koninklijke Nederlandse Academie van Wetenschapen.

Vos A (2001) Scholasticism and Reformation. In Van Asselt WJ and Dekker E (eds) Reformation and Scholasticism, pp. 99-119.

Webster J (2007) Theologies of Retrieval. In Webster J, Tanner K, and Torrance I (eds) The Oxford Handbook of Systematic Theology. Oxford: Oxford University Press, pp. 583-599. 